\title{
ANALISIS KADAR VITAMIN C, KALSIUM DAN POSFORUS PADA CABAI RAWIT (Capsicum frustescens $L$.) HASIL PENGAWETAN
}

\section{Analysis of Vitamin C, Calcium and Phosphorus Levels in Cayenne Pepper (Capsicum frustescens L.) of Preservation Result}

\section{*Ida Nurjannah, Sri Mulyani Sabang, dan Afadil}

Pendidikan Kimia/FKIP - Universitas Tadulako, Palu - Indonesia 94118

Received 03 September 2018, Revised 08 October 2018, Accepted 13 November 2018

\begin{abstract}
This study aimed to determine the levels of vitamin $C$, calcium and phosphorus of the preserved chili pepper. In this research, two preservation techniques were applied, cooling and drying. For analysis of vitamin $C$ was used the iodometric method, the results obtained in the technique of cooling was $11.08 \mathrm{mg} / 100 \mathrm{~g}$ and the drying technique was $9.85 \mathrm{mg} / 100 \mathrm{~g}$. For calcium and phosphorus analysis was analyzed by using the spectrodirect instrument, research result obtained for calcium in the cooling technique was $20.00 \mathrm{mg} / \mathrm{L}$ and the drying technique was $12.33 \mathrm{mg} / \mathrm{L}$ while for phosphorus of the cooling technique was $27.66 \mathrm{mg} / \mathrm{L}$ and the drying technique was $55.16 \mathrm{mg} / \mathrm{L}$.
\end{abstract}

Keywords: chili pepper, vitamin C, calcium, posforusus, iodometric method, and spectrodirect

\section{Pendahuluan}

Cabai rawit (capsicum frustescens L.) merupakan komoditas buah-buahan yang banyak mengandung vitamin $\mathrm{C}$, kalsium dan posforus dengan kadar masing-masingnya yaitu $70 \mathrm{mg}, 45 \mathrm{mg}$ dan $85 \mathrm{mg}$ dalam 100 g cabai rawit (Rukmana, 2002). Cabai rawit juga tergolong buah-buahan yang mudah rusak karena disebabkan oleh sifat komponen-komponen penyusunnya terutama pada kadar air yang tinggi yaitu $71,2 \%$ sehingga sulit untuk mempertahankan cabai rawit dalam bentuk segar (Rukmana, 2002). Umumnya cabai rawit memiliki daya simpan yang rendah. Artinya, cabai hanya dapat bertahan sekitar 12 hari saja setelah dipanen. Cabai rawit yang rusak memiliki perubahan fisik antara lain perubahan warna dari warna merah segar berubah menjadi coklat kehitaman dan berbintik-bintik hitam dan perubahan tekstur yaitu cabai menjadi lunak dan keriput (Rukmana, 2002). Karena hal tersebut agar pemanfaatan cabai rawit dapat bertahan lebih lama oleh konsumen, maka perlu dilakukannya teknik pengawetan.

Teknik pengawetan yang dilakukan dapat memungkinkan terjadinya kerusakan vitamin C, kalsium dan posforus dalam cabai rawit dan menghilangkan sebagian besar warna dan tekstur yang khas dari cabai (Rahayu, 2012). Oleh karena itu, dibutuhkan proses pengawetan yang tepat dan baik yang tidak mengakibatkan terjadinya penurunan signifikan kandungan vitamin $\mathrm{C}$, kalsium dan Posforus dalam cabai rawit.

Vitamin C merupakan vitamin yang larut dalam air dan bekerja sebagai suatu koenzim dan pada keadaan tertentu merupakan reduktor dan antioksidan. Vitamin C ini dapat secara langsung atau tidak langsung memberikan elektron ke enzim yang

${ }^{*}$ Correspondence:

Ida Nurjannah

Program Studi Pendidikan Kimia, Fakultas Keguruan dan Ilmu Pendidikan, Universitas Tadulako

e-mail: idanurjannah@gmail.com

Published by Universitas Tadulako 2018 membutuhkan ion-ion logam tereduksi \& bekerja sebagai kofaktor untuk prolil dan lisil hidroksilase dalam biosintesis kolagen. Zat ini berbentuk kristal dan bubuk putih kekuningan, stabil pada keadaan kering (Dewoto, 2007). Vitamin C stabil dalam bentuk kristal, namun mudah teroksidasi dalam larutan menjadi dehidro askorbat yang juga memiliki fungsi bioligis dalam tubuh manusia, penyimpanan yang kurang baik mengakibatkan vitamin $\mathrm{C}$ mudah teroksidasi menjadi asam dehidroaskorbat (Wijarno, 2002). Asam ini secara kimia juga sangat labil dan mengalami perubahan lebih lanjut menjadi asam Ldiketogulonat yang tidak lagi memiliki keaktifan sebagai vitamin C. Suasana basa menyebabkan asam L-diketogulonat teroksidasi menjadi asam oksalat dan asam L-treonat (Hastuti, 2007).

Kalsium (Ca) merupakan unsur hara semimikro yang dibutuhkan tanaman. Di dalam tanah ketersediaan hara Ca dalam bentuk kation yang dapat dipertukarkan. Unsur ini meupakan bagian dari basa-basa tanah yang banyak berkaitan erat dengan keasaman tanah dan ketersediaan aluminium dapat dipertukarkan. Kadar $\mathrm{Ca}$ yang tinggi dalam tanah umumnya berpengaruh terhadap keasaman tanah (Hafid, 2015). Kalsium juga dapat membantu mempertahankan kadar pektin ionik yang lebih tinggi dan berkontribusi untuk menjaga integritas struktural dinding sel,dimana kalsium berperan sebagai konsekuensi pengendapan kalsium pada polisakarida pektin (Lara, 2004).

Posforus memiliki bentuk yang tidak murni tidak memiliki warna transparan. Beberapa bagian tanaman banyak mengandung unsur posforus yaitu bagian-bagian yang bersangkutan dengan pembiakan generatif seperti daun-daun, bunga, tangkai sari, kepala sari, butir tepung sari, daun buah dan bakal biji sehingga untuk pembentukan bunga dan buah sangat banyak diperlukan unsur selain itu posforus juga berperan pada sintesis hijau daun. Posforus mendorong pertumbuhan akar-akar muda yang berguna bagi resistensi terhadap kekeringan 
(Semangun, 2006). Polifosfat ditambahkan secara langsung untuk mencegah terjadinya pembentukan karat dan korosi pada peralatan logam dalam bidang industri. Posforus tidak bersifat toksik bagi manusia, hewan dan ikan. Posforus merupakan unsur hara terbanyak yang dibutuhkan oleh tanaman setelah nitrogen. Posforus merupakan unsur hara makro yang ketersediannya sangat ditentukan oleh sifat dan karakteristik tanahnya, antara lain oleh $\mathrm{pH}$, kandungan $\mathrm{Al}, \mathrm{Fe}, \mathrm{Mn}, \mathrm{Ca}$ dan bahan organik di dalam tanah. Posforus di dalam tanah senantiasa diikat oleh $\mathrm{Fe}$, $\mathrm{Al}$ dan $\mathrm{Ca}$ dalam bentuk senyawa (Basyuni, 2009).

Pengawetan pada cabai rawit bertujuan untuk mencapai umur simpan semaksimal mungkin dan menjaga kandungan cabai rawit agar tidak mengalami penurunan vitamin $\mathrm{C}$, kalsium dan posforus secara signifikan. Usaha yang dapat dilakukan untuk dapat memperlambat pematangan cabai rawit adalah memperlambat respirasi dan menangkap gas etilen yang terbentuk. Perubahan-perubahan fisik kimia yang umumnya terjadi pada buah-buahan selama pematangan dan pengawetan diantaranya adalah tekstur, warna, kandungan gula, keasaman, susut bobot, kadar air dan kandungan vitamin C. Ketersediaan hayati semua trans $\beta$-karoten dari sayuran bergantung antara lain pada hubungan molekuler dan matriks makanan di mana ia digabungkan (Bernhardt, 2005). Berdasarkan penelitian yang dilakukan Rachmawati (2009), bahwa cabai dapat bertahan sampai dengan 10 hari ketika cabai diawetkan dalam lemari pendingin pada suhu $10{ }^{\circ} \mathrm{C}$. Pengaruh pendinginan terhadap cabai rawit diantaranya penurunan suhu akan mengakibatkan penurunan proses kimia, proses mikrobiologi, proses biokimia yang berhubungan dengan kerusakan atau pembusukan. Perlakuan suhu rendah merupakan cara efektif dalam mereduksi laju respirasi dan menghambat kerusakan akibat jamur. Pendinginan akan mengurangi kelayuan serta kehilangan air, menurunkan laju reaksi kimia dan laju pertumbuhan mikroba pada bahan yang disimpan. Pengawetan pada suhu rendah bertujuan menekan kecepatan respirasi agar berjalan lebih lambat sehingga ketahanan simpan akan lebih lama dengan mutu yang relatif masih baik (Nurmawanti, 2008). Sedangkan pada pengeringan dapat mengeluarkan atau menghilangkan sebagian air suatu bahan dengan atau tanpa bantuan energi panas. Pengeringan merupakan proses pemindahan panas dan uap air secara simultan, yang memerlukan energi panas untuk menguapkan kandungan air yang dipindahkan dari permukaan bahan, yang dikeringkan oleh media pengering yang biasanya berupa panas. Tujuan pengeringan adalah mengurangi kadar air bahan sampai batas dimana perkembangan mikroorganisme dan kegiatan enzim yang dapat menyebabkan pembusukan terhambat atau terhenti. Oleh karena itu, bahan yang dikeringkan dapat mempunyai waktu simpan yang lebih lama. Dasar pengeringan adalah terjadinya penguapan air ke udara karena perbedaan kandungan air antara udara dengan bahan yang dikeringkan. Kandungan uap air udara lebih kecil atau udara mempunyai kelembaban yang relatif rendah sehingga terjadinya penguapan (Widyani, 2008).

Tulisan ini mendeskripsikan penentuan kadar vitamin C, kalsium dan posforus pada cabai rawit setelah dilakukan pegawetan dengan metode pendinginan dan pengeringan.

\section{Metode}

Alat-alat yang digunakan dalam penelitian ini adalah spectrodirect Lovibond, neraca digital, lemari pendingin, wadah, blender, gelas ukur, erlenmeyer, klem dan statif, spatula, batang pengaduk, corong, botol semprot, pipet tetes, lumping dan alu, labu ukur, gelas kimia, oven, vial, furnance, gegep, desikator dan cawan penguap. Sedangkan bahanbahan yang digunakan dalam penelitian ini adalah cabai rawit, aquades, indikator amilum (Merck), serbuk KI (Merck), iodin (Merck), kertas saring, larutan asam nitrat pekat (Merck), reagen hardness tablets Lamotte, reagen phosphate acid Lamotte dan phosphate reducing Lamotte.

\section{Cara kerja}

Cabai rawit yang bersih disimpan dalam ruangan pendingin selama 7 hari, kemudian cabai rawit dihaluskan untuk dianalisis kandungan vitamin $\mathrm{C}$, kalsium dan posforus.

Analisis vitamin C menggunakan metode iodimetri (titrasi langsung). Sedangkan untuk analisis kalsium dan posforus menggunakan spectrodirect. Proses menentukan kadar kalsium dan posforus cabai rawit, cabai harus diabukan terlebih dahulu dengan cara 0,8 gram sampel cabai yang sudah dioven ditambahkan 4,4 mL $\mathrm{HNO}_{3}$ dan disaring untuk mendapatkan filtratnya yang kemudian diencerkan dengan aquades pada labu ukur $100 \mathrm{~mL}$. Setelah itu memasukkan ke dalam 3 buah vial masing-masing 10 $\mathrm{mL}$ dan menambahkan masing-masing reagen. 


\section{Hasil dan Pembahasan}

Berdasarkan hasil yang diperoleh dari metode iodimetri untuk analisis vitamin $\mathrm{C}$ tertera pada Tabel 1.

Tabel 1. Hasil analisis vitamin c pada cabai rawit

\begin{tabular}{clc}
\hline No & $\begin{array}{l}\text { Teknik Pengawetan } \\
\text { pada Cabai Rawit }\end{array}$ & $\begin{array}{c}\text { Vitamin C } \\
(\mathbf{m g} / \mathbf{1 0 0 g})\end{array}$ \\
\hline 1 & Pendinginan & 11,08 \\
2 & Pengeringan & 9,85 \\
\hline
\end{tabular}

Tabel 1 menunjukkan bahwa kadar vitamin $\mathrm{C}$ lebih tinggi pada teknik pendinginan. Hal ini dikarenakan perlakuan dengan suhu dingin merupakan cara yang efektif dalam mereduksi laju respirasi dan menghambat pertumbuhan jamur. Selain itu, proses pendinginan memiliki hasil vitamin $\mathrm{C}$ yang tinggi dikarenakan aktivitas air pada proses pendinginan dapat diturunkan ke tingkat yang mencegah aktivitas mikroba dan mengurangi tingkat reaksi kimia. Proses pendinginan itu sendiri menghasilkan jaringan yang signifikan terhadap kerusakan struktur, tergantung pada tingkat dan suhu masing-masing yang diterapkan. Pengurangan kerusakan akibat pendinginan dapat dilakukan dengan menurunkan suhu secara bertahap sebelum penyimpanan. Sedangkan dengan dilakukannya pengawetan pada suhu yang tinggi atau pengeringan dapat menurunkan asam askorbat menjadi lebih cepat. Sehingga kerusakan yang terjadi menyebabkan jaringan-jaringan mudah terpengaruh oleh udara dan memungkinkan vitamin $\mathrm{C}$ rusak karena teroksidasi oleh udara menjadi asam dehidroaskorbat. Dehidro-asam askorbat (asam Ldehidroaskorbat) merupakan bentuk oksidasi dari asam L-askorbat yang masih mempunyai keaktifan sebagai vitamin $\mathrm{C}$, namun asam L-dehidro-askorbat bersifat sangat labil dan dapat mengalami perubahan menjadi 2,3 L-diketogulonat yang terbentuk tidak mempunyai keaktifan vitamin $\mathrm{C}$ lagi sehingga jika terbentuk akan mengurangi bahkan menghilangkan vitamin $\mathrm{C}$ yang ada dalam produk (Barreta, 2011). Walaupun pengeringan merupakan cara yang paling penting untuk memperpanjang daya simpan suatu bahan, namun dapat berpengaruh menurunkan zat-zat makanan yang terkandung dalam bahan tersebut dan ini sangat tergantung pada berat/lamanya proses pengeringan.

Hasil ini sejalan dengan hasil penelitian pada cabai rawit putih oleh Rachmawati (2009), yaitu suhu berpengaruh nyata terhadap kandungan vitamin $\mathrm{C}$, dimana semakin tinggi suhu maka kandungan vitamin $\mathrm{C}$ semakin menurun. Hal ini disebabkan oleh terjadinya proses respirasi dan oksidasi vitamin $\mathrm{C}$ menjadi asam L-dehidroaskorbat dan mengalami perubahan lebih lanjut menjadi asam L-diketogulonat yang tidak memiliki keaktifan vitamin $\mathrm{C}$.

Tabel 2. Hasil analisis kalsium (Ca) pada cabai rawit

\begin{tabular}{clc}
\hline No & $\begin{array}{l}\text { Teknik Pengawetan } \\
\text { pada Cabai Rawit }\end{array}$ & $\begin{array}{c}\text { Kalsium }(\mathrm{Ca}) \\
(\mathrm{mg} / \mathrm{L})\end{array}$ \\
\hline 1 & Pendinginan & 20 \\
2 & Pengeringan & 2,33 \\
\hline
\end{tabular}

Tabel 3. Hasil analisis posforus (P) pada cabai rawit

\begin{tabular}{clc}
\hline No & $\begin{array}{l}\text { Teknik Pengawetan } \\
\text { pada Cabai Rawit }\end{array}$ & $\begin{array}{c}\text { Posforus }(\mathrm{P}) \\
(\mathrm{mg} / \mathrm{L})\end{array}$ \\
\hline 1 & Pendinginan & 27,66 \\
2 & Pengeringan & 55,16 \\
\hline
\end{tabular}

Tabel 2 menunjukkan bahwa kadar Ca lebih tinggi pada teknik pendinginan dan rendah pada teknik pengeringan, hal ini disebabkan karena salah satu sifat senyawa Ca yang mudah menguap, sehingga ketika cabai diawetkan pada teknik pengeringan maka senyawa $\mathrm{Ca}$ yang terkandung di dalam cabai rawit akan lebih banyak menguap dibandingkan senyawa $\mathrm{Ca}$ yang berada pada teknik pendinginan. Menurut Panjinugroho (2016), semakin tinggi suhu dalam suatu reaksi pada Ca maka akan memberikan tekanan yang lemah, tumbukan yang terjadi pada teknik pengeringan akan semakin sedikit, sehingga kecepatan reaksi akan berjalan lambat.

Untuk kandungan Posforus yang ditunjukkan pada Tabel 3, hasil yang diperoleh pada teknik pengeringan memiliki presentase lebih tinggi, hal ini disebabkan karena pada teknik pengeringan, kandungan Posforus memiliki kelarutan mengikat hidrogen yang lebih tinggi. Hal ini sesuai dengan penelitian yang dilakukan oleh Winarno (2008), bahwa proses pemasakan dapat mengakibatkan terjadinya pemutusan interaksi mineral dengan komponen pangan lain seperti protein, karbohidrat, lemak serta vitamin dan komponen lainnya. Molekulmolekul berbagai senyawa dalam makanan terikat satu sama lain dalam ikatan hidrogen. Pemanasan dapat mengurangi daya tarik-menarik antara molekulmolekul air dan akan memberikan cukup energi kepada molekul-molekul air tersebut sehingga dapat mengatasi daya tarik-menarik antar molekul dalam bahan tersebut. Karena itu daya kelarutan pada bahan yang melibatkan ikatan hidrogen, akan meningkat dengan meningkatnya suhu.

Kelarutan mineral dapat meningkat atau menurun tergantung pada proses pengeringan atau pendinginan. Pengeringan tidak menjamin mineral akan terlarut seratus persen karena banyak faktor yang dapat menghambat kelarutan mineral, di antaranya perubahan struktur kimia seperti 
denaturasi protein. Mineral pada makanan dapat berubah struktur kimianya pada proses pemasakan atau akibat interaksi dengan bahan lain. Pemanasan diketahui dapat menyebabkan protein menjadi terdenaturasi, hal ini dapat berinteraksi dengan mineral sehingga menyebabkan mineral sulit untuk larut. Menurut Wardhayani (2010), bahwa proses pengolahan dapat bersifat negatif karena dapat terjadi pengaktifan enzim yang bersifat menghambat dan membuat mineral menjadi komponen yang sulit larut, tetapi proses pengolahan juga dapat bersifat menguntungkan terhadap beberapa komponen zat gizi yang terkandung dalam bahan pangan, yaitu perubahan kandungan zat gizi, peningkatan daya cerna dan ketersediaan zat-zat gizi serta penurunan berbagai senyawa antinutrisi yang terkandung di dalamnya serta dapat meningkatkan sifat bioavailablenya. Pemanasan yang berlebihan dapat menyebabkan penurunan nilai sensoris dan nilai gizi produk pangan olahan, untuk itu kunci utama dalam proses pengolahan bahan pangan, baik tingkat rumah tangga maupun di industri adalah melakukan optimisasi proses pengolahan untuk menghasilkan produk olahan yang secara sensoris menarik dan tinggi nilai gizinya.

\section{Kesimpulan}

Berdasarkan hasil penelitian yang telah dilakukan dapat disimpulkan bahwa kadar vitamin $\mathrm{C}$ setelah dilakukan teknik pengawetan pada pendinginan yaitu $11,08 \mathrm{mg} / 100 \mathrm{~g}$ dan pada pengeringan yaitu $9,85 \mathrm{mg} / 100 \mathrm{~g}$. Kadar mineral Ca pada pengawetan pendinginan yaitu $20,00 \mathrm{mg} / \mathrm{L}$ dan kadar P yaitu 27,66 mg/L dan untuk pengawetan pengeringan kadar $\mathrm{Ca}$ yang diperoleh yaitu 12,33 $\mathrm{mg} / \mathrm{L}$ dan kadar P yaitu 55,16 mg/L.

\section{Ucapan Terima Kasih}

Penulis mengucapkan terima kasih kepada semua pihak yang telah membantu dalam pelaksanaan penelitian ini.

\section{Referensi}

Barreta, D. M. (2011). Advanced preservation methods and nutrient retention in fruits and vegetables. Journal Science Food Agriculture, $2011(92), 7-22$.

Basyuni, Z. (2009). Mineral dan batuan sumber unsur hara P dan K. Purbalingga: Universitas Jendral Soedirman.

Dewoto, H. R. (2007). Vitamin dan mineral dalam farmakologi dan terapi. Jakarta. Percetakan Gaya Baru.
Diharnaini., Tuljannah, N., \& Hamzah, B. (2013). Ekstraksi ion tembaga (II) dengan metode emulsi membran cair menggunakan ditizon sebagai pembawa kation. Skripsi. Palu: Universitas Tadulako.

Hafid, I. (2015). Analisis kadar kalsium (Ca) dan fosfor (P) pada limbah sisik dan sirip ikan mujair (Oreochromis mossambicus) dari danau Lindu Sulawesi Tengah. Skripsi. Palu: Universitas Tadulako.

Hastuti, E. D. (2007). Pengaruh suhu dan lama penyimpanan terhadap penurunan kadar vitamin c brokoli (Brassica oleracea L.). Jurnal Anatomi dna Fisiologi, $X V(2)$, 40-41.

Lara, I. (2004). Modifications in cell wall composition after cold storage of calcium-treated strawberry (Fragaria $x$ ananassa duch) fruit. Postharvest Biology and Technology, 34(3), 331339.

Nurmawanti, N. E. (2008). Pengaruh pra pendinginan dan subu penyimpanan terhadap mutu buah mangga cengkir indramayu. Skripsi. Bogor: Institut Pertanian Bogor.

Panjinugroho, F. D. (2016). Pengaruh temperatur dan $z$ at adiktif asam sitrat 20 ppm pada pembentukan kristal $\mathrm{CaSO}_{4}$ (Kalsium sulfat). Semarang: Universitas Muhammadiyah Semarang.

Prajnanta, F. (1995). Agribisnis cabai hibrida. Bekasi: Penebar Swadaya.

Puspitasari. (2009). Daya Antioksidan vitamin c buah tomat yang beredar di pasar manonda palu berdasarkan lama penyimpanan. Skripsi. Palu: Universitas Tadulako.

Rachmawati, R., Deviani, M.R., \& Suriani, N.L. (2009). Pengaruh suhu dan lama penyimpanan terhadap kandungan vitamin c pada cabai rawit putih (Capsicum frustescens). Jurnal Biologi, $\operatorname{XIII}(2), 36-40$.

Rahayu, E.S. (2012). Kadar vitamin dan mineral dalam buah segar dan manisan basah karika dieng (Carica pusbescens lenne \& k.koch). Jurnal Biosaintifika, 4(2), 90-97.

Rukmana, R. (2002). Usaha tani cabai rawit. Yogyakarta: Kanisisus.

Semangun, H. (2006). Penyakit-penyakit tanaman perkebunan di Indonesia. Yogyakarta: Gadjah Mada University Press.

Setiadi. (1986). Bertanam cabai. Bekasi: Penebar Swadaya.

Wardhayani, Y.K., Nurjanah., \& Abdullah, S. (2010). Karakteristik fisik dan kimia tepung cangkang kijing lokal (Pilbryoconcha exilis). Jurnal Pengolahan Hasil Perikanan Indonesia, XIII(1), 48-49.

Wirdyani, R. (2008). Prinsip pengawetan makanan. Cirebon: Swagati Press.

Wijarno. (2002). Analisa hasil pertanian. Malang: Universitas Brawijaya 